\begin{tabular}{|c|c|c|c|c|c|c|c|c|c|}
\hline B. $24 \mathrm{I}$ & I 901 & Juli & I 9 & $9^{h} 5^{8 \cdot} \cdot 3-$ & $\mathrm{I} 3^{\mathrm{h}} 48^{\mathrm{m}} \cdot 3$ & Z. & Kgst. am & Bruce & Teleskop \\
\hline B 2.42 & $\gg$ & $》$ & I 9 & $958.6-$ & $\times 348.6$ & $\gg$ & $s$ & $»$ & ? \\
\hline B 838 & I903 & Sept. & 24 & $7 \times 3.7-$ & I I I 3.7 & $\gg$ & $\gg$ & 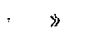 & $》$ \\
\hline В 839 & 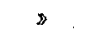 & $»$ & 24. & $7 \times 4.0-$ & I I I 4.0 & . & . & $»$ & $\gg$ \\
\hline
\end{tabular}

Zur Scbätzung der Helligkeit habe ich vorläufig nur diese Platten herangezogen. Die Schätzung ist durch Vergleichung mit den photographischen Bildern einiger Plejadensterne erhalten und dürfte besonders bei den am Rande gelegenen Variabeln ziemlich ungenau sein. Die Größe der

\begin{tabular}{|c|c|c|c|c|}
\hline Nr. & $\begin{array}{c}\text { Var. } \\
\text { Aquilae }\end{array}$ & $\begin{array}{l}\text { Bezeich. } \\
\text { a. Platte }\end{array}$ & $\begin{array}{l}\mathbf{1 9 0 \mathbf { I }} \\
\text { Juli I.9 }\end{array}$ & $\begin{array}{c}\text { I } 903 \\
\text { Juli } 24\end{array}$ \\
\hline I & $64 \cdot 1903$ & $g$ & II: 5 & I5 \\
\hline 2 & 65.1903 & $m_{1}$ & 14 & I 2.5 \\
\hline 3 & 66.1903 & $c_{1}$ & $<14$ & I 3 \\
\hline 4 & $67 \cdot 1903$ & $d$ & I I.O & 14.5 \\
\hline 5 & 68.190 .3 & $\left.d_{1}{ }^{1}\right)$ & $<$ I 4 & I 3 \\
\hline 6 & $\mathrm{RV}$ & $h_{1}$ & I 3 & 10.5 \\
\hline 7 & 69.1903 & $\left.l_{1}^{2}\right)$ & I 4 & I I. 5 \\
\hline 8 & 70.1903 & $a$ & 12.0 & 14.5 \\
\hline 9 & 71.1903 & $k$ & Ir:O & $<Y_{5}$ \\
\hline IO & $72: 1903$ & $e_{1}$ & $<$ I 5 & $x_{3} .5$ \\
\hline Ir & 73.1903 & $f_{1}$ & $<15$ & 14 \\
\hline 12 & 74.1903 & $k_{1}$ & I $3 \cdot 5$ & I r \\
\hline
\end{tabular}

Bei dem ungeheuren Sternreichtum der Gegend um $\gamma$ Aquilae - es ist die Gegend um $\gg$ die dreifache Höhle im Adler * - ist es nicht verwtunderlich, dab ich hier so viele Veränderliche fand. Es gibt aber ebenso sternreiche

Gr. Astrophys. Observatorium Königstuhl-Heidelberg, 1903 Dezember.

genden, wo die Ausbeute ein Minimum ist. Hierzu ge hört z. B. die Gegend um $\xi$ Cygni, die fast ganz frei von Veränderlichen ist. Das ist sehr merkwürdig. beobachteten Schwankung ist weniger ungenau. Ich hebe hervor, daß ich nur Sterne mit großen Schwankungen hier angeführt habe, sodaß also jeder Zweifel über die Realität der Veränderlichkeit ausgeschlossen erscheint.
1) Nahe nördlich von einem hellen Stern.

a) Der südich vorangehende eines Paares.

\title{
Direct and retrograde Rotation of the Planets.
}

\section{By William H. Pickering.}

It was early recognized as a serious objection to the nebular hypothesis of Laplace that the inner edge of the assumed planetary ring would travel faster than the outer one, so that when the ring broke up to form a planet, the rotation of the latter would be retrograde instead of direct. Laplace suggested that owing to friction of its constituents the ring would practically revolve as one piece. This was obviously impossible. Kirkwood suggested ${ }^{1}$ ) that owing to tidal action by the Sun, the retrograde rotation of a diffuse gaseous mass would first cease and then a direct rotation be established, the planet constantly presenting the same face to the Sun. As the planet condensed he thought the speed of rotation would increase in spite of the tides, until velocities such as we find at the present day were obtained. Faye suggested that the inner planets were formed inside of the nebula, before it had condensed, thus giving these a direct rotation, while Uranus and Neptune were formed later, after condensation, therefore having a retrograde motion.
Trowbridge proposed the idea that the rings from which the inner planets were formed were very dense along their inner edges, thus giving these planets a direct rotation, while in the case of the outer planets the rings were of a more uniform structure.

There are two objections to all of these hypotheses, first that they explain the rotation of Neptune in a different manner from that of the other planets, and second that they do not explain the rotation of Uranus at all. The inclination of the orbits of the satellites of Uranus it will be remembered is $9^{\circ}$, and as this doubtless coincides very closely with the plane of the planet's equator, this plane is practically perpendicular to the planet's orbit. It was shewn by the writer ${ }^{2}$ ) that the varying planes of rotation of the planets may be very simply accounted for by the well known laws of motion, without the introduction into the discussion of any new hypotheses whatever.

It is certain that when the original planetary rings for

1) American Journal of Science, I864, XXXVII, I

?) Astronomy and Astro-Physics, 1893, XII, 487; Astronomical Journal, I9or, XXII, 56. 
spirals) broke up, the resulting planets cannot all have re. volved in a retrograde direction. The action of the tides produced on them by the Sun would not however, as Kirkwood supposed, have tended to destroy this motion, but simply to have changed the plane of its rotation. To demonstrate this, let $A B$ represent the plane of the equator of Uranus, when this plane passes through the Sun. Let $A C$ represent the plane of the planet's orbit, and let us imagine the planet beyond the Sun. Let $A B$ represent the course of a point on the planet's equator due to the planet's rotation on its axis. The attraction of the

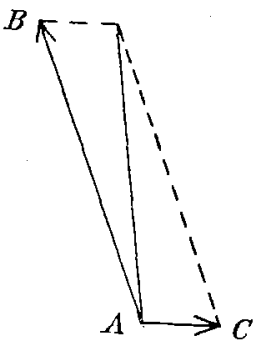
Sun producing an annual tide on the planet will generate a force $A C$, which will tend to cause the point $A$ to follow a more nearly vertical direction than it otherwise would. This force will diminish as the planet proceeds in its orbit, becoming zero after a quarter revolution. A quarter of a revolution later, when the plane of rotation again passes through the Sun, the direction of motion and the disturbing force will both be in the opposite direction for the side of the planet nearest the Sun, but the effect on the plane of the planet's rotation will be the same. It will tend to revolve in the direction of the hands of a watch, constantly becoming more and more inclined to the plane of its orbit. The process will continue without intermission until ultimately the two planes coincide, and a direct rotation is established such as has already practically occurred in the case of Jupiter. The force $A C$ acts in a direction at right angles to that which produces precession. A practical demonstration of this course of reasoning is readily obtained with a gyroscope.

Harvard College Observatory, Cambridge Mass. U.S. A., I go3 Oct. 7.

William H. Pickering.

Beobachtungen von kleinen Planeten.

\begin{tabular}{l|c|c|c|c|c|c|c|c|c|c|}
\hline I904 & M. Ortszeit & $\Delta \alpha$ & $\Delta \delta$ & Vgl. & Gr. & $\alpha$ app. & $\log p . \Delta$ & $\delta$ app. & $\log p . \Delta \mid$ Red. ad l. app. & $*$ \\
\hline
\end{tabular}

(409) Aspasia [1904 MZ], beob. auf der k. k. Sternwarte in Wien.

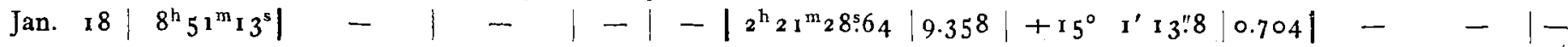
Beobachter Dr. F. Palisa.

(409) Aspasia [1904 MZ], beob. auf der Sternwarte in Düsseldorf.

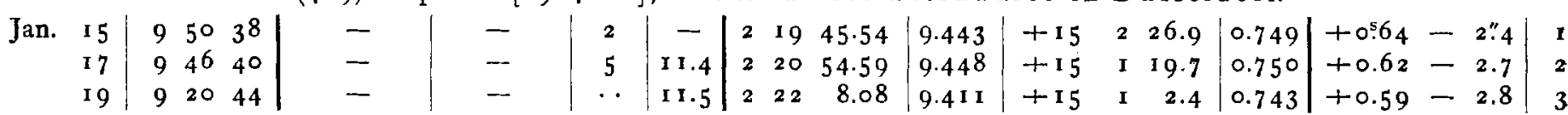

Beobachter W. Luther. Jan. I5. Position sehr unsicher; Planet bei schlechter Luft kaum zu sehen. - Jan. I 7 . Sichere Beobachtung während einer kurzen Aufheiterung.

(470) Kilia, beob. auf der Sternwarte des Collegio Romano in Rom.

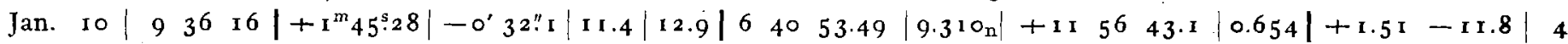
Beobachter Dr. E. Bianchi.

1904 NA, beob. auf der Sternwarte in Düsseldorf.

Jan. $22\left|\begin{array}{lll}11 & 15 & 45\end{array}\right|-|\quad-| 6|11.3| 44647.18|9.393|+23940.8|0.660|+1.38-6.7 \mid 5$

Beobachter $W$. Luther. Die Korrektion der Ephemeride von (505) [1902 LL] beträgt hiernach $+1^{\mathrm{m}} 5^{\mathrm{s}}+9^{\prime} 7$, so dab die Identität beider Planeten sehr wahrscheinlich wird.

$1904 \mathrm{NB}$, beob. auf der Sternwarte des Collegio Romano in Rom.

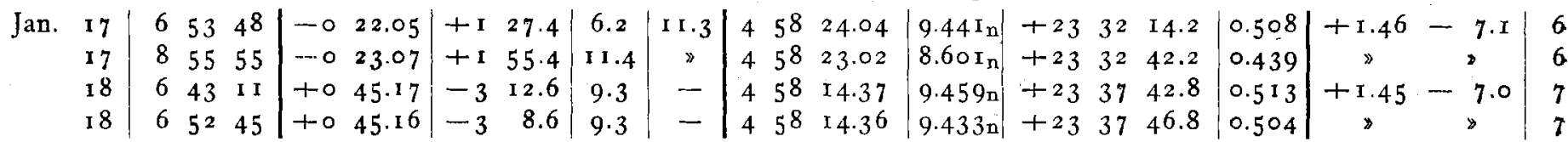

Die erste Beobachtung an jedem Tage ist von Prof. E. Millosevich, die zweite von Dr. E. Bianchi angestellt.

Mittlere Örter der Vergleichsterne.

\begin{tabular}{|c|c|c|c|c|c|c|c|}
\hline * & $\alpha$ I 904.0 & $\delta 1904.0$ & Autorität & $*$ & $\alpha 1904.0$ & $\delta 1904.0$ & Autorität \\
\hline 1 & $2^{\mathrm{h}} \times 6^{\mathrm{m}} 31^{\mathrm{s}} .96$ & $\operatorname{tr} 5^{\circ} 4^{\prime} 49^{\prime \prime} \mathrm{o}$ & $\begin{array}{l}1 / 2 \text { (AG. Leipzig I } 684+ \\
\text { Berlin A. } 65^{\circ} \text { ) }\end{array}$ & $\begin{array}{l}4 \\
5\end{array}$ & 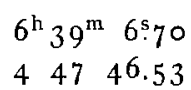 & $\begin{array}{l}+1 r^{\circ} 57^{\prime} 27^{\prime \prime} 0 \\
+23922.5\end{array}$ & $\begin{array}{l}\text { AG. Leipzig I } 2458 \\
\text { AG. Berlin B. I } 549\end{array}$ \\
\hline 2 & $\begin{array}{lll}2 & 18 & 3.49\end{array}$ & $+145^{8} 3^{2.1}$ & AG. Leipzig I 690 & 6 & $\begin{array}{lll}4 & 5^{8} & 44.63\end{array}$ & +233053.9 & $\gg \quad 1629$ \\
\hline & $2 \quad 18$ I.1 7 & $+145^{828.4}$ & Bonn. Veröff. 4 & 7 & $4 \quad 57 \quad 27.75$ & +2341 & $\times \quad 1614$ \\
\hline
\end{tabular}

